\title{
Can Mechanical Stress Therapies be used in COVID-19 outbreak?
}

\author{
Muhammad Ali ${ }^{1}$ and Muhammad Haider ${ }^{2}$ \\ ${ }^{1}$ Awan Clinic \\ ${ }^{2}$ Allied Hospital Faisalabad
}

May 5, 2020

\begin{abstract}
Understanding the workings of the novel coronavirus (SARS-CoV-2) is crucial to develop counter therapeutic measures. SARSCoV-2 gains entry into human cell by binding its receptor Binding Domain (RBD) of Spike protein (S1) to ACE2 receptors. In order to study the effect of mechanical stress on the RBD of SARS-CoV-2, it is modelled as viscoelastic material using Burgers Model. Strain response of RBD under constant stress is analyzed, which gives useful insights into the conformational transitions of RBD at $\mathrm{OK}$ and physiological temperatures. The theoretical underpinning has shown that with increase in the number of stress cycles, the binding affinities of RBD conformational states to ACE2 receptor decrease, decreasing the binding reaction rate between ACE2 receptor and SARS-CoV-2. This analysis gives theoretical evidence that ultrasonic therapy and photo therapy (UV) can be potential candidates to reduce binding reaction rates between ACE2 and SARS-COV-2.
\end{abstract}

\section{Hosted file}

Manuscript(Proteins).pdf available at https://authorea.com/users/316816/articles/446954-canmechanical-stress-therapies-be-used-in-covid-19-outbreak 